$\S=-1$

\title{
Experimental Study of Using Bentonite Concrete with and Without Crimbed Steel Fiber in Conventional Concrete.
}

\author{
R.Kalaiselvan1 , J.Madhan kumar2 ,B.Raghul raj3 . \\ ,2\&3.Department of Civil Engineering, Vel Tech High Tech Dr.Rangarajan Dr.Sakunthala Engineering College, \\ *Corresponding author E-mail: kalaiselvan2689@gmail.com.
}

\begin{abstract}
Cement manufacturing pollutes atmosphere by release of greenhouse gases like carbondioxide and it depletes the ozone layer causing adverse affect on livings on earth by global warming. Due to this reason mineral admixtures are added to concrete to reduce carbondioxide emmision in concrete.various type of mineral admixtures are available fly ash, silica fume, rice husk, sea shell and a cheaper clay material bentonite is considered and used in this project.This paper presents the result of an experimental investigation carried out to evaluate the properties of concrete with bentonite and steel fiber bentonite in which ordinary portland cement was partially replaced with bentonite by weight for a mix of M25 grade concrete. Replacing of cement by bentonite and bentonite with steel fiber was carrird out, concrete was casted and tested for the compressive strength, split tensile strength and flexural strength. Mix of bentonite with conventional concrete for various percentage and the results have been tabulated and compared with conventional concrete. Then, the same properties were examined in concrete adding different percentages of crimed steel fiber by weight of concrete with constant amount of bentonite which in turn increases the strength of concrete
\end{abstract}

Keywords: crimbed steel fibers, Steel fiber reinforced concrete, Bentonite, Flexural strength, Split tensile strength.

\section{Introduction}

Most widely used construction material around the world is Concrete.Concrete is the composite material of combination of cement, fine aggeregate and coarse aggregate and water in proportion. Binding material for concrete is the cement (ordinary Portland cement). Cement production is primary source for the emission of the greenhouse gas $\mathrm{CO}_{2}$, which is the main cause for Global warming. So it is a need replace the cement by some natural materials having pozzolanic properties. Bentonite is a natural material having pozzolonic properties. This investigation of the study is to replace cement with bentonite by proportions with and without crimmed steel fibres "as discussed by Amritha E.K and Neethu Paul [1]". Due to replace of cement by pozzolonic bentonite by proportions which leads to low tensile strength and ductility which leads to concrete weakness and brittleness in concrete.To overcome this crimmed steel fibres were used "as studied by shafeeq ahamed, brijbhushan s, maneeth p.d[2]". S.A.Memon, R.Arsalan, S. Khan, and T.Y.Lo [3] "had found bentonite mix showed increase in strength at 56 days compared to control mix and better to acid attack than control mix". Hamdy K.Shehab Eldin, Heba A. Mohamed, Mahmoud Khater, Sayed Ahmed[4] "as found mechanical properties of concrete increased by addition of crimped steel fibre by fractions compared to normal concretre". M.V.Mohod.[5] stated that "addition of steel fibres will increase tensile strength and increase in steel fibres will reduce workability in concrete". E. Cokca. and Z. Yilmaz[6] "have found rubber and bentonite added fly ash showed good result for construction of a liner". J. Akbar, B. Alam and M. Ashraf[7] have evaluated and concluded that Bentonite showed compressive strength at later stage and durability purposes it gives good results at every stage. W.H. Huang[8] "have discussed about the properties Properties of cement - fly ash grout admixed with bentonite, Silica fume, or organic fiber." J. Thomas and A. Ramaswamy[9] "have evaluated the Mechanical properties of steel fiber reinforced concrete"

[10]M.Karthikeyan1,P.RajaRamachandrn,A.Nandhini,R. Vinodha (2015) "have found Partial Substitute of Cement by Bentonite in Concrete increases the compressive strength and durability"

\section{Material Specifications}

\subsection{Odinary Portland Cement}

As per IS 4031:1968 OPC 53 have been used. The properties of cement tested were Fineness $2.81 \%$, Normal consistency $28.5 \%$, specific gravity 3.2 .

\begin{tabular}{|c|c|c|}
\hline $\begin{array}{c}\text { Initial cement } \\
\text { (grams) }\end{array}$ & Water & Readings \\
\hline 400grams & $25 \%(100 \mathrm{ml})$ & 23 \\
\hline 400grams & $27 \%(108 \mathrm{ml})$ & 12 \\
\hline 400 grams & $28 \%(112 \mathrm{ml})$ & 10 \\
\hline 400grams & $28.5 \%(114 \mathrm{ml})$ & 7 \\
\hline
\end{tabular}

Consistency test for cement

\subsection{Fine Aggregate}

Fine aggregates are termed as "filler" which fills the voids in concrete. The fractions of aggregates less then $4.75 \mathrm{~mm}$ are known as 
fine aggregates. The river sand is used as fine aggregate conforming to requirement of IS:383-1970 come under zone II

\begin{tabular}{|c|c|c|c|c|}
\hline IS Sieve & Weight & Cummulative & Cummulative & Cummulative \\
\hline size mm & $\begin{array}{c}\text { Retained } \\
\text { grams }\end{array}$ & $\begin{array}{c}\text { Weight retained } \\
\text { grams }\end{array}$ & $\begin{array}{c}\text { Percentage } \\
\text { retained grams }\end{array}$ & $\begin{array}{c}\text { Percentage } \\
\text { passing in grams }\end{array}$ \\
\hline 4.75 & 0 & 0 & - & 100 \\
\hline 2.36 & 23 & 23 & 4.6 & 95.4 \\
\hline 1.18 & 129 & 152 & 30.4 & 69.6 \\
\hline $600 \mu$ & 168 & 320 & 64 & 36 \\
\hline $300 \mu$ & 145 & 465 & 93 & 7 \\
\hline $150 \mu$ & 31 & 495 & 99.2 & 0.8 \\
\hline Pan & 4 & 500 & - & - \\
\hline
\end{tabular}

Fineness modulus $=208.8 / 100$ $=2.08$

\subsection{Coarse Aggregate}

Aggregate fraction larger than $4.75 \mathrm{~mm}$ are termed as coarse aggregates used in the experimental work passed in $20 \mathrm{~mm}$ sieve are retained on $10 \mathrm{~mm}$ IS Sieve comes under zone II aggregates conforming to IS: 383-1970.The physical properties of the coarse aggregate Fineness Modulus - 7.70, Specific Gravity -2.81

\subsection{Bentonite}

Natural sodium bentonite was used. Heat treatment was given to the bentonite at $100^{\circ} \mathrm{C}$. The physical properties were Fineness $10.6 \%$, Specific gravity $-2.62, \mathrm{pH}-9.56$, sand content $-1.4 \%$, swelling-12times.

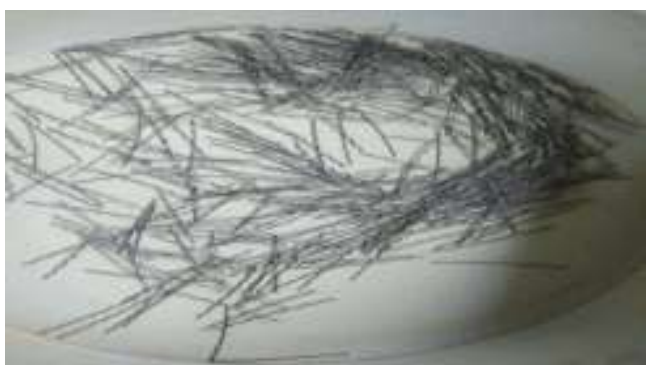

Fig.1: Bentonite

\subsection{Steel Fibre}

As per ASTM- A820M Crimped steel fibers used. Properties of steel fibers were Properties of steel fibers were Length - $50 \mathrm{~mm}$, diameter $-0.8 \mathrm{~mm}$, aspect ratio -62 .

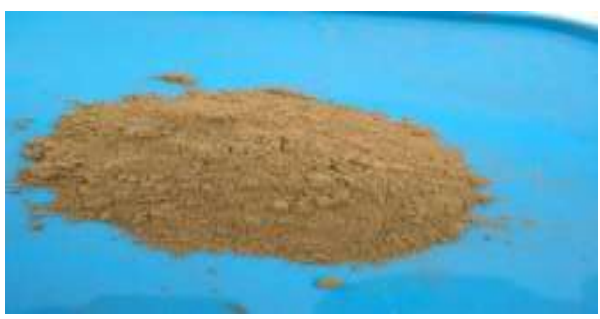

Fig. 2: Steel Fiber

\subsection{Water}

Water have been added as per IS: 456- 2000.

\section{Concrete Mix Design}

Based on trial mixes for different proportions of mix was prepared for M25 grade concrete as per IS 10262-2009. The mix proportion is $1 ; 1.7 ; 3$ and $w / c$ ratio -0.5 .
Table 1: Mix design

\begin{tabular}{|c|c|}
\hline Cement ko $/ \mathrm{m}^{3}$ & 39432 \\
\hline Fine aggregate $\mathrm{kg} / \mathrm{m}^{3}$ & 671.84 \\
\hline Coarse aggregate $\mathrm{kg} / \mathrm{m}^{3}$ & 1184.696 \\
\hline Water in litres & 197.16 \\
\hline
\end{tabular}

\section{Casting of Specimens}

The specimens were casted based on mix proportions. Sodium based Bentonite was used in this investigation at $5 \%, 10 \%, 15 \%$, $20 \%$, and $25 \%$ replacement of cement by weight. Crimbed steel fibers were also included at various percentages in the concrete containing $15 \%$ replacement of cement by bentonite. The steel fiber content is varied as $0.5 \%, 1 \%, 1.5 \%$ and $2 \%$ of total weight of concrete. The different specimens like cubes, cylinders and prisms as per the requirement of test were cast. Cubes $150 \mathrm{~mm} \times 150 \mathrm{~mm} \times 150 \mathrm{~mm}$, cylinders with $150 \mathrm{~mm}$ diameter and $300 \mathrm{~mm}$ height and prisms of size $100 \mathrm{~mm} \times 100$ $\mathrm{mm} \times 500 \mathrm{~mm}$ were prepared using the standard moulds.

\section{Specimen Notations}

11 mixtures were prepared by varied content and fiber content. Specimens were casted by addition of bentonite and designated B, where B represents bentonite content. Different mixes are listed in Table 2.

Table2:

\begin{tabular}{|c|c|c|}
\hline Mix & Bentonite content (\%) & $\begin{array}{c}\text { Steelfiber } \\
\text { content(\%) }\end{array}$ \\
\hline B0 & $0 \%$ & $0 \%$ \\
\hline B5 & $5 \%$ & $0 \%$ \\
\hline B10 & $10 \%$ & $0 \%$ \\
\hline B15 & $15 \%$ & $0 \%$ \\
\hline B20 & $20 \%$ & $0 \%$ \\
\hline B25 & $25 \%$ & $0 \%$ \\
\hline B15CSF0 & $15 \%$ & $0 \%$ \\
\hline B15CSF0.5 & $15 \%$ & $0.5 \%$ \\
\hline B15CSF1 & $15 \%$ & $1 \%$ \\
\hline B15CSF1.5 & $15 \%$ & $1.5 \%$ \\
\hline B15CSF2 & $15 \%$ & $2 \%$ \\
\hline
\end{tabular}

\section{Testing Of Specimens}

The compressive strength, flexural strength and split tensile strength of different mixes were found out at 28 days as per the procedure laid down in IS: 516 - 1959.

\section{Result and Discussion}

\subsection{Workability}

The workability of concrete mixtures was measured by performing slump cone test. Slump cone values is $80 \mathrm{~mm}$.

\subsection{Compressive Strength}

Compressive strength of concrete with varied bentonite was determined at 7 and 28 days. Compressive strength by adding varied percentage of steel fiber in concrete at 7 and 28 days were determined. Different percentage of bentonite and steel fiber result has been given in Figure 3 and 4. 

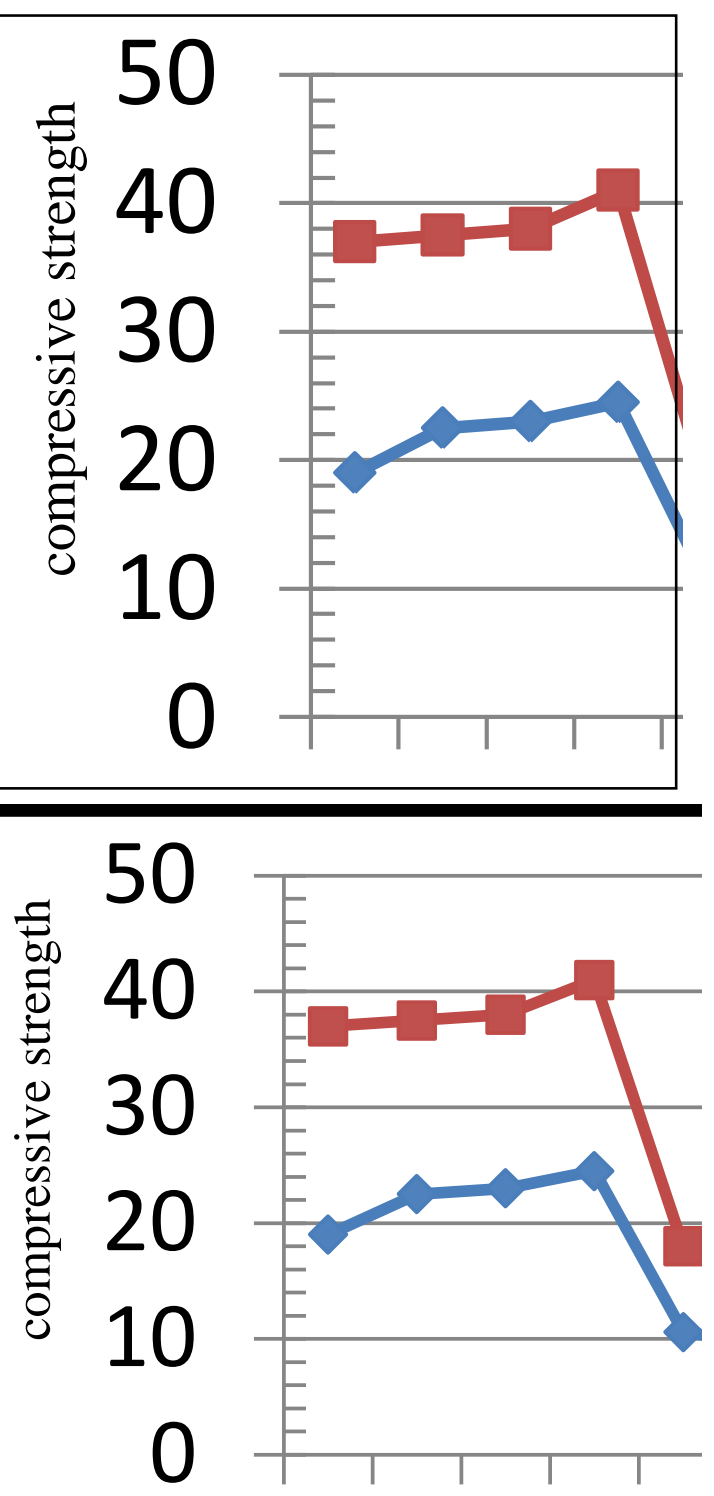

ก $1 \cap$ ก!

Figure3: compression strength of Bentonite without steel fiber

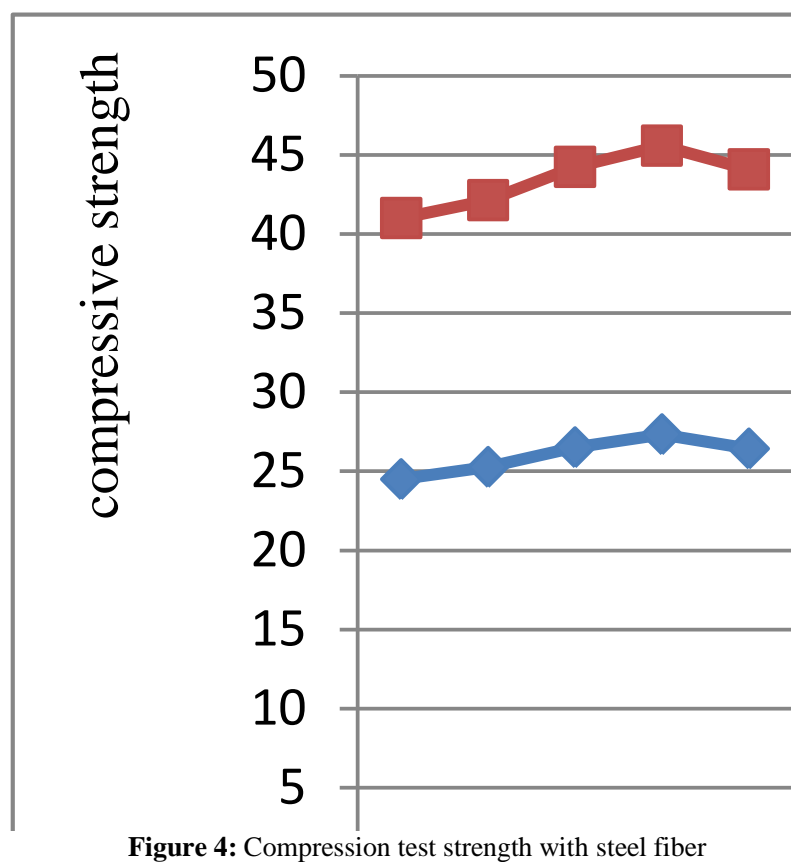

\subsection{Split Tensile Strength}

Split tensile strength of concrete with varied percentage of bentonite was determined at 7 and 28 days. Split tensile strength by adding varied percentage of steel fiber in concrete at 7 and 28 days were determined. Different percentage of bentonite and steel fiber result have been given in Figure 5 and 6 .

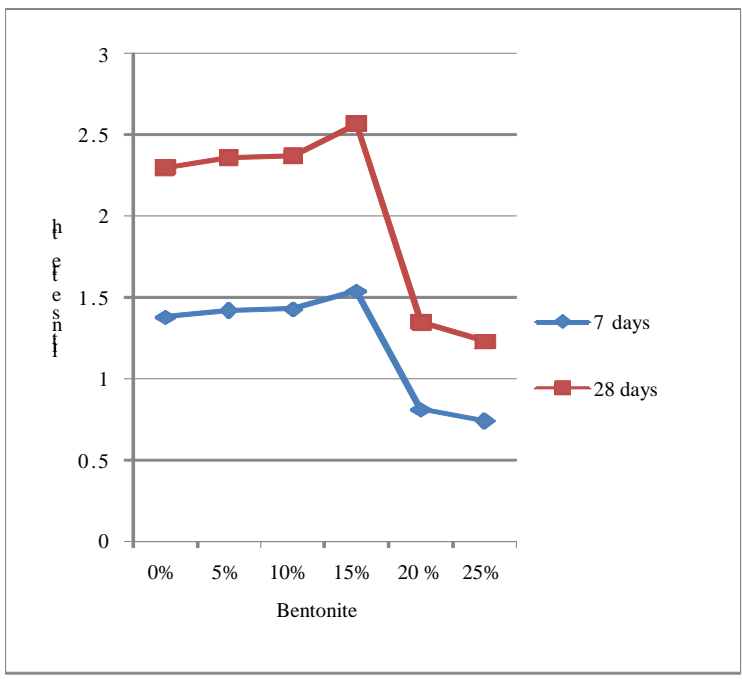

Fig.5: Split tensile strength without steel fiber

The split tensile strength was increased slightly up to the mix B15 compared to the control mix. After that the strength was decreased. With this B15 mix steel fibres were added at various percentage. As a result the tensile strength of B15 mix was increased upto $1.50 \%$ addition of steel fiber and then decreased in adding steel fibres as show in fig: 6

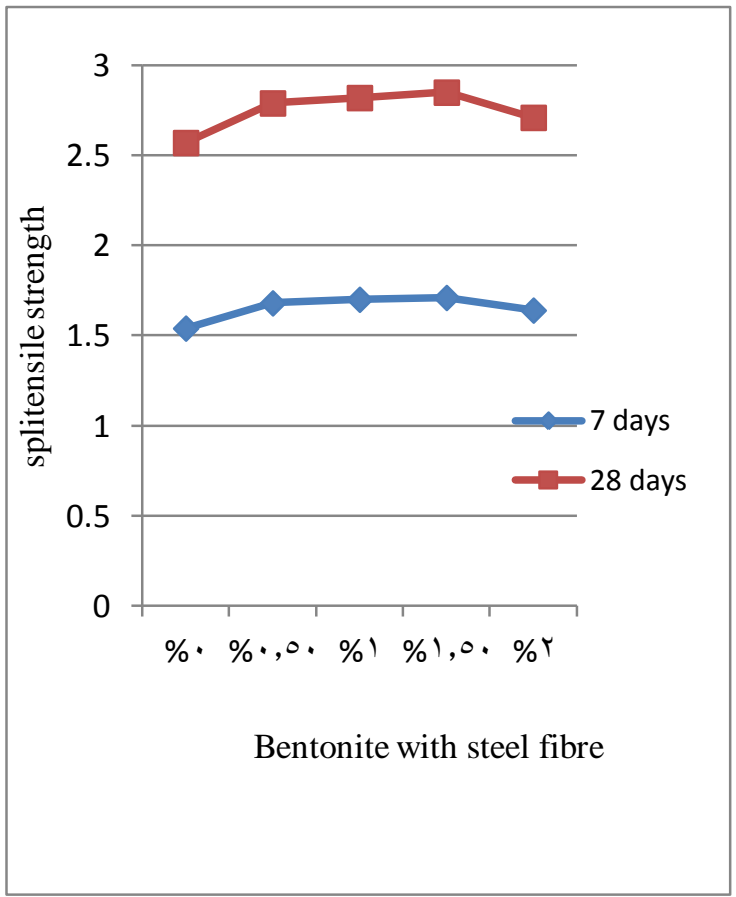

Fig. 6: Split tensile strength with steel fiber

\subsection{Flexural Strength}

Flexural strength of concrete mixes made with bentonite and $15 \%$ bentonite with steel fiber were determined. Different percentage of bentonite and steel fiber result have been given in Figure 7 and 8. 


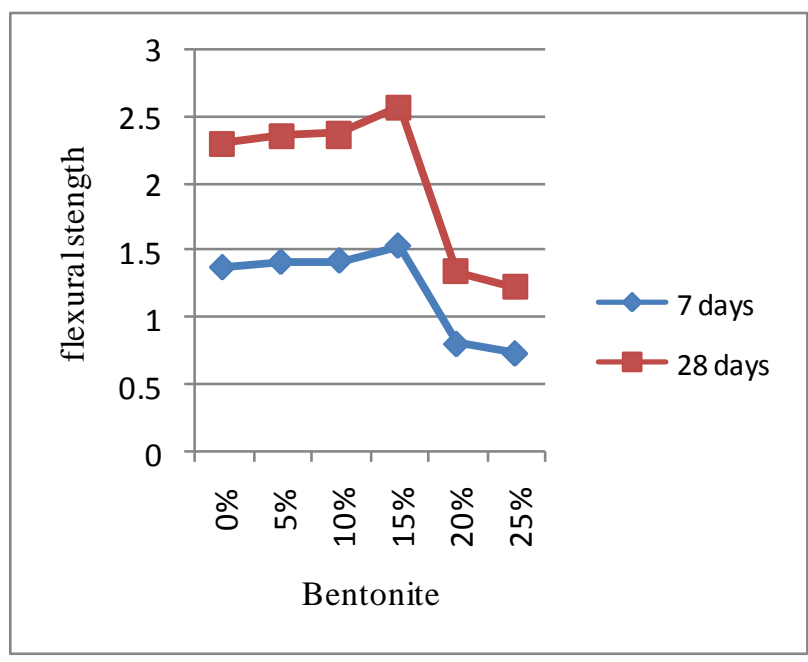

Fig.7: Flexural strength without steel fiber

The flexural strength for the mix B15 have attained maximum value when compared with conventional concrete. With this B15 mix steel fibres were added at various percentage. As a result the flexural strength of B15 mix was increased upto $1.50 \%$ addition of steel fiber and then decreased in addition of steel fibres as show in fig: 8

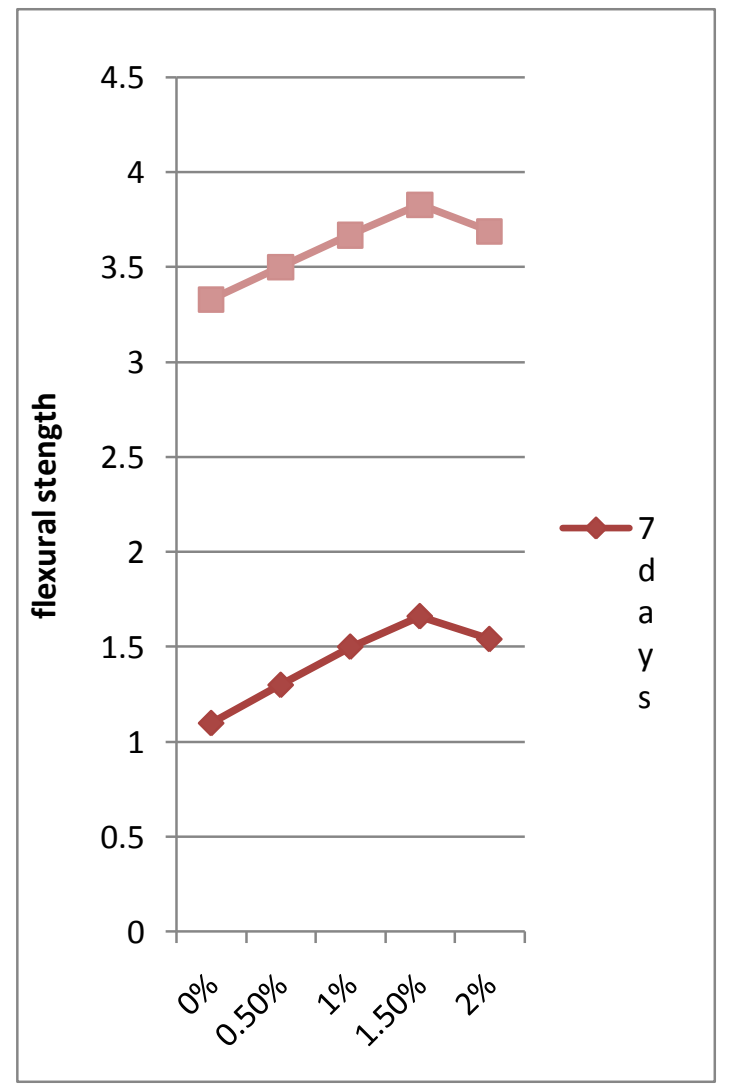

Fig.8: Flexural strength with steel fiber

\section{Conclusions}

Replacing of cement by bentonite and bentonite with steel fiber was carrird out, concrete was casted and tested for the compressive strength, split tensile strength and flexural strength. Mix of bentonite with conventional concrete for various percentage and the results have been tabulated and compared with conventional concrete. In 15 percentage mix gave a satisfactory result and steel fiber for various percentages of $0.5 \%, 1 \%, 1.5 \%, 2 \%$ have been added from which $1.5 \%$ addition of steel fibers attains a maximum strength and decreases at $2 \%$ addition of steel fibers .

\section{References}

[1] Amritha E.K and Neethu Paul (2016) "Evaluation of the Properties of Bentonite Concrete with and without Steel Fiber" Volume 7, Issue 10, October-2016 162 ISSN 2229-5518

[2] [2] Shafeeq ahamed, brijbhushan s, maneeth p.d (2017)“an experimental investigation on steel fiber reinforced concrete with partial replacement of natural sand by m-sand"

[3] volume: 04 issue: 07 |july -2017

[4] S.A.Memon, R.Arsalan, S. Khan, and T.Y.Lo.(2012). "Utilization of Pakistani Bentonite as partial replacement of cement in concrete." Construction and building materials.,Vol-30, 237-242.

[5] Mechanical Properties ofUltra-High Performance Fiber Reinforced Concrete. International Journal of Engineering and Innovative Technology (IJEIT) Volume 4, Issue 4, October 2014. Hamdy K.Shehab Eldin, Heba A. Mohamed, Mahmoud Khater, Sayed Ahmed Department of Structural Engineering, faculty of engineering, Zagazig University, Zagazig, Egypt. ISSN: 2277-3754.

[6] M.V Mohod. (2012). "Performance of steel fiber Reinforced Concrete."International Journal of Engineering and Science., Vol-1, No-12, 1-4.

[7] E. Cokca. and Z. Yilmaz. ( 2004). "Use of rubber and bentonite added fly ash as a liner

[8] material." Waste Management., Vol.24 ,153-164.

[9] J. Akbar, B. Alam and M. Ashraf. (2013). "Evaluating the effect of Bentonite on strength and Durability of High Performance Concrete." International Journal of Advanced Structures Geotechnical Engineering., Vol.2, No.1, 1-5.

[10] W.H. Huang. (1997). "Properties of cement - fly ash grout admixed with bentonite, Silica fume, or organic fiber." Cement and Concrete Research., Vol-27, No-3, 395-406.

[11] J. Thomas and A. Ramaswamy. (2007) "Mechanical properties of steel fiber reinforced concrete." Journals of materials in Civil Engineering., Vol-9,No-5, 385-392.

[12] M.Karthikeyan1,P.RajaRamachandrn,A.Nandhini,R. Vinodha (2015)"Application on Partial Substitute of Cement by Bentonite in Concrete"Vol.8, No.11 pp 384-388, 2015. SSN: 0974-4290. 